\title{
Integrated Competence-Based Approach to Teaching Russian as a Foreign Language
}

\author{
O.A. Dmitrieva \\ Department of Russian as a Foreign Language \\ Volgograd State Socio-Pedagogical University \\ Volgograd, Russia
}

\author{
I.A. Korolyova \\ Department of Russian as a Foreign Language \\ Volgograd State Socio-Pedagogical University \\ Volgograd, Russia
}

\author{
A.V. Pravdikova \\ Department of Russian as a Foreign Language \\ Volgograd State Socio-Pedagogical University \\ Volgograd, Russia
}

\begin{abstract}
The article deals with the competence-based approach to language education and its application to teaching Russian as

Foreign Language. The authors emphasize the importance of integrated development of the communicative and cultural competences in the teaching and learning process since language and culture are closely interrelated and cannot be understood or acquired separately. The relative practical experience is described to illustrate the theoretical thesis. The innovative method of modeling a linguocultural personality type in the process of students' research work is used as an example of an effective way of developing cultural awareness.
\end{abstract}

Keywords - communicative competence; cultural competence; language education; Russian as a Foreign Language; integrated competence-based approach

\section{INTRODUCTION}

The new paradigm for higher education in Russia sets forth the competence-based approach. The Federal Educational Standards specify certain universal and professional competences, the development of which is viewed as the ultimate goal of higher education. The success of the course of study can be assessed by the graduates' ability to demonstrate the knowledge, skills and abilities which constitute the corresponding competence. Unlike the knowledge-based curricula, the competence focused programs include subjects and practical activities aimed at teaching students the skills required to perform specific tasks relating to the particular field of study. Two of the universal humanitarian competences as described in the most recent Federal Standards relate to communication (language competence) and intercultural interaction (culture-related competence). The UC-4 for undergraduate programs states that university graduates must "be able to carry out official communication in spoken and written forms in the state language of the Russian Federation and a foreign language (or languages)" and UC-5 specifies that they must "be able to recognize cultural diversity in society within social, historical, ethical and philosophical contexts" [1]. The corresponding competences for graduate programs emphasize abilities "to use modern communicative technologies, including those in a foreign language (or languages), for academic and professional interaction" (UC-4) and "to analyze and recognize cultural diversity in the process of intercultural interaction" (UC-5) [2].

Language education (both teaching and learning) has long been viewed in terms of competence-building. Firstly, it was considered to be aimed at building communicative competence, i.e. the learner's ability to communicate successfully in various situations using the language means. In recent years, however, culture-related competences have been put forward in recognition of the close interdependence between language and culture. Ultimately, the two types of competences are complimentary and equally essential to acquiring language proficiency. So the purpose of this research is to revise the concept of competence-based language teaching and to explore the ways it can be applied to teaching Russian as a Foreign Language (RFL).

The perspective and relevance of the research is determined by the adoption of competence-based paradigm in Russian educational system and the necessity to incorporate the findings and methods of international teaching community into Russian classroom practices. At the same time it is important to preserve those national traditions of teaching Russian which are worth keeping and which have proved to be useful and effective.

\section{COMPETENCES INVOLVED IN LANGUAGE LEARNING}

\section{A. Communicative Competence}

Communicative competence is defined as a person's ability to use language to communicate successfully. The original term was introduced by Dell Hymes [3]. 
The concept was further elaborated on by Canale and Swain [4] who described the communicative competence as encompassing four components: grammatical competence, which includes knowledge of phonology, orthography, vocabulary, word formation and sentence formation; sociolinguistic competence including knowledge of sociocultural rules of use or social appropriacy of certain language means; discourse competence dealing with cohesion and coherence in different types of texts; and finally, strategic competence relating to the use of communication strategies. The communicative approach to teaching RFL was first introduced in 1969 by E.I. Passov [5] and has since been promoted and elaborated on by various Russian scholars (A.R. Arutyunov, A.A. Leontyev, O.D. Mitrofanova and others).

The objective of teaching RFL in this perspective shifts from acquiring knowledge about the Russian language system to forming skills and strategies for using it to perform all kinds of speech activities (both receptive and productive). The communicative competence within this framework basically adds up to three components: the linguistic component, the sociolinguistic component and the pragmatic component. None of these three must be underestimated or overlooked in the process of teaching RFL.

The linguistic component of the communicative competence relates to acquiring knowledge and skills at all the levels of the language system: phonetics, vocabulary and grammar.

The sociolinguistic component of the communicative competence deals with the ability to differentiate between and choose the appropriate language means, to use and modify them according to the context.

The pragmatic subcompetence includes knowledge and skills necessary for understanding and generating speech within the particular communicative situation, and according to the particular communicative intention.

In addition, the notion of the communicative competence has a broader meaning not only limited to the language learning context. "Communicative competence is a synthesis of the social, perceptive, reflective, auto psychological, psychological pedagogical competences and related skills. The high level of development of the competence allows communicating effectively in a team of professionals in order to achieve their goals" [6].

\section{B. Culture-related Competences}

The importance of teaching and learning the culture along with the language is universally recognized among the language teachers today. Cultural awareness has been considered an essential part of language education for the last few decades, and even more so now, with the political processes in the world bringing new challenges of promoting cultural and ethnic tolerance. Various aspects of cultural awareness are recognized by scholars and language teachers and they identify specific types of culture-related competences.

European scholars (Byram, Zarate, Neuner, Gribkova, Starkey) use the terms sociocultural or intercultural competence. The sociocultural competence is defined as the ability "to interpret and bring different cultural systems into relation with one another, to interpret socially distinctive variations within a foreign cultural system, and to manage the dysfunctions and resistances peculiar to intercultural communication..." [7]. These authors argue that the aim of language and cultural training is not the ultimate assimilation of the language learners with the native speakers, but developing an intercultural personality open to new experiences and tolerant toward other cultures [8]

In Russian tradition the culture-related competence in language learning is defined as the liguocultural competence. The linguocultural competence encompasses both language proficiency and cultural awareness, enabling the student of a foreign language to understand and, to a certain degree, embrace the national worldview of its native speakers. The development of the linguocultural competence is based on both theoretical and practical foundations. The theory includes researching the components of the national worldview, specifically linguocultural concepts and cultural values which are reflected in the language system at all levels, but particularly so in its vocabulary. While teaching a foreign language it is important to select the essential basic components of the language system (key words, collocations, idioms and texts) reflecting the cultural identity of the society which is defined by the system of national values and enabling the person to carry out productive interaction in a foreign communicative environment.

Building the linguocultural competence is based on the interdisciplinary approach. It employs not only linguistic data and methods but also those of psychology as well. Modern research in psychology addresses a number of issues pertaining to building cultural awareness. Various crosscultural studies explore different aspects of a foreign language acquisition.

The goal of teaching a foreign language is not only training a person to communicate but also destroying negative ethnic stereotypes by means of expanding and redefining the students' knowledge about the representatives of a different culture.

An important part of developing the linguocultural competence is overcoming the prejudices and preconceptions about the foreign culture and its representatives and the erroneous interpretation of the symbols underlying its various phenomena. To that end it seems appropriate to use the theory of linguistic types or personas developed within the framework of the linguocultural approach [9].

\section{THE APPLICATION OF INTEGRATED COMPETENCE-BASED APPROACH TO RFL CLASSROOM}

Active interaction in the process of teaching Russian to foreign students is based on a number of factors including the mutual influence of cultures, national worldview, the ethnic identity and psychological idiosyncrasy of each student, etc. Learning the Russian language is closely linked with developing cultural awareness which involves not only acquiring some cultural knowledge but also the ability and 
readiness to recognize the cultural differences as well as the awareness of the students' own cultural identity including their native language, culture and mentality.

The activity-based approach as described in the Law of the Russian Federation on Education and the Federal Education Standard provides means for: 1) designing and constructing the social environment for the students' progress; 2) organizing the teaching process with due regard to the students' age, their psychological and physiological makeup; 3 ) encouraging the students' personal growth and lifelong learning; 4) organizing the students' effective learning and cognitive activity.

Language is one of the key identification features of a nation so it serves as a source of knowledge of the national culture. Learning the language involves getting extralinguistic information both in special country studies classes and during the regular classes of grammar and speech practice. All kinds of culture-related information are incorporated in language lessons starting at the basic level. The very first lessons include Russian names, forms of addressing adults and children, elementary social formulas, speech patterns used in various situations. Textbooks also include proper names and place names along with all kinds of visual materials (maps, photos, pictures of key geographical features and cultural landmarks) which aim at engaging all of the student's perceptive apparatus.

The use of literary texts (including national poetry) enables students both to broaden their cultural outlook and study the functions of particular lexical units and syntactical structures. In addition, studying literary works contributes to the students' ability to carry out etymological, lexical and contextual analysis. In RFL classes teachers create conditions to introduce their students to all the functional styles of the language. The students imitate various communicative situations which may arise in the course of interacting with the native speakers within both formal and informal settings.

The cultural material verbalized in proverbs, sayings and idioms, which are often hard to interpret due to the lexical gaps, use of archaic words and difficult proper names, is at the same time an invaluable source of information about Russian culture, history and traditions.

Due to the large number of textbooks and study guides it is important to define the principles for choosing the best options which would be most effective in RFL classes. The main criteria for the selection should be the relevance of the information and materials in the textbook and their communicative potential. The image of modern-day Russia is not always represented in textbooks accurately. On the one hand, some authors tend to portray archaic Russia with traditional wooden houses and men in fur hats, the stereotyped "traditional Russia". On the other hand, many authors describe modern Russian life in very negative terms picking up on all the social problems. Neither attitude is conducive to successful introduction to the Russian language or culture. Without glossing over the real life difficulties, it is still essential to concentrate on the positive aspects of the national culture as it would promote students' interest and motivation for language learning.

It is very important to choose the teaching material carefully because in the process of learning Russian students acquire a new perspective on life in Russia. There is a crosscultural aspect to learning, when students compare their own culture and language with the ones they study. They ask questions such as "Why do you say that?" or "How do you do it in Russia?" and state that in their own culture they do or say it differently. It is an important part of language education which also helps students to recognize and appreciate their own cultural identity.

Extracurricular activities also play an important role in language education. Field trips, festivals, sightseeing tours and other activities allow for the natural acquisition of certain language features through real-life experiences. Such exposure to Russian culture and lifestyle helps to overcome the language barriers and culture shock. Indeed, it is in this kind of setting that the students' practical language skills are put to test.

It must be said that RFL instruction has a long tradition of working with students outside the classroom. There are Russian language clubs, Russian-speaking meetings and socials, language contests, visits to museums and theatres, etc. The key to the success of these forms of work is the interdependence between the classroom material and its application outside classroom.

Working on some grammar topics can serve as an example to illustrate the interdependence between the theoretical framework and its practical use in RFL class. One example is teaching to use impersonal sentences. After discussing the theory of expressing general impersonal meaning in Russian grammar, students are offered practical tasks and situations encouraging them to use these grammatical structures. The language material includes various rules and regulations, proverbs and sayings. Then students can be asked to speak about national traditions, festivals and celebrations. All these topics involve using impersonal sentences in Russian. The culture-based material makes it interesting and motivating so the difficult grammar structures are learned more easily in the communicative situations. When learning the use of the verbs of motion (another difficult part of Russian grammar) students can be asked to speak about their travelling experiences. A walking tour of the city can also be incorporated as a practical part. Learning noun and adjective declension can be made easier and even enjoyable if it is practiced by speaking about interesting topics such as national cuisine, favorite dishes and recipes. In order to motivate students, the tasks must be creative. For example, speaking about national cuisine can be illustrated with pictures and photos, or even a real-life international food festival or cooking contests.

The role of the teacher in constructing the effective learning environment cannot be overestimated. The teacher not only instructs in the language usage, but also forms the attitudes towards the language and culture, promotes its positive image. If the students fail to recognize the cultural 
component in the material, it is the teacher's task to highlight and explain it.

An essential part of higher education is training students to carry out research work. Studying the linguistic and cultural issues is especially important for the students majoring in linguistics. The topics which are offered for the research and writing thesis works are often related to both language and culture. They may include linguocultural concepts and linguocultural types. Both notions have been successfully used in students' research and have proved both enlightening and educationally beneficial.

The linguocultural concept is a multifaceted unit of national mentality and worldview. There are various approaches to defining the notion, but basically it is viewed as a quantum of knowledge having three important dimensions: notional, iconic and evaluative. Concepts are part of the national culture; they describe the way a representative of the given culture categorizes the objective reality. At the same time concepts are necessarily verbalized through the language means and thus can be studied and taught.

Comparative studies of significant cultural concepts have proved to be an effective way of building cultural awareness in RFL students. While working on comparing the concepts of such basic phenomena as love, friendship, family, happiness and misery, work and leisure, etc. students learn to recognize the differences in mental images as well as the constitutive components of the notions as well. Most important, they learn to appreciate the cultural values expressed through the concepts. The theory of linguocultural personality types has emerged within the framework of cognitive linguistics. It deals with the typical images of certain personalities which are culturally determined. The concept of a typical teacher, or grandmother, or patriot, etc. will vary from culture to culture, and although the corresponding words denoting these personas can be found in every language, the concepts and images would be quite different.

While modelling a linguocultural type students study Russian national mentality, national beliefs and values, types of communicative behaviour. At the same time national stereotypes are reevaluated and corrected, which leads to overcoming cultural differences and developing ethnic tolerance. The experience-based, applicable nature of the theory of linguocultural types enables the students not only to recognize Russia's linguistic and cultural uniqueness but also to compare it to their own by drawing on the ethnic, historic, social and psychological data in the process of modelling the linguocultural types. The research procedure is defined and structured so that the students need to go through certain stages. First, an association experiment is carried out. The respondents are asked to write a response to the verbal stimulus such as 'a Russian teacher', 'like a Russian teacher' and the like. Next, corresponding dictionary definitions are analyzed as well as contexts from the texts belonging to different genres describing the type under study. Visual images are also considered. The results show not only the verbal component of the linguistic personality but the cultural attitudes to that type as well. To select the language material students, use a number of methods, namely, the methods of cultural meanings analysis, ethnographic method, the method of conceptual analysis, the method of dictionary definitions, the method of interpretative analysis, questionnaire survey, interviewing, direct observation, association experiment, semiotic analysis. As a result of the research a linguocultural type is modelled and described according to the specific scheme. During the research process the students study various historical and literary sources and enrich their knowledge of Russian culture. They also learn the rules of communicative behavior, etiquette and social norms pertaining to the national culture, determined by cultural values and verbalized in the national vocabulary.

\section{CONCLUSION}

In conclusion, the competence-based approach to language education is not an entirely new notion for teachers of Russian as a Foreign Language. It has been to a certain degree practiced in RFL classroom for quite a long time. The new aspect is structuring and describing the competences involved in language learning in terms of particular knowledge, skills and abilities which should be taught ad evaluated at the end of the course of study.

The universally recognized competences are the communicative competence (including the linguistic, sociolinguistic and pragmatic subcompetences) and culturerelated competence (including the intercultural or crosscultural, sociocultural and linguocultural competences). Since teaching and learning a foreign language is an integral multitask process involving all kinds of activities and goals, the competences taught are also interrelated and interdependent. It is quite impossible to teach people to communicate successfully in a foreign environment without introducing them to the culture, its specific features, norms and values. Thus, in application to a foreign language classroom it seems appropriate to speak of integrated communicative-cultural approach which includes all of the above-mentioned competences.

\section{References}

[1] Federal state educational standards for Bachelor's degree specializations. Retrieved from: http://fgosvo.ru/fgosvo/151/150/24

[2] Federal state educational standards for Master's degree specializations. Retrieved from: http://fgosvo.ru/fgosvo/152/150/25

[3] D.H. Hymes, "On Communicative Competence." Sociolinguistics: Selected Readings, ed. by J. B. Pride and J. Holmes, Penguin, 1985, pp. 269-293.

[4] M.Canale, M. Swain, "Theoretical bases of communicative approaches to second language teaching and testing". Applied Linguistics, vol.1 (1), pp. $1-47,1980$.

[5] E.I. Passov. The method of culture dialogue. Express-reflection on the development of methodical science. Lipetsk, 2011. p. 2.

[6] A.A. Isakova, "Integrated communicative method as form of cooperation between teacher and student (from work experience)". Advances in Social Science, Education and Humanities Research (ASSEHR), vol. 97, p. 5, 2017.

[7] M. Byram, G. Zarate, G. Neuner, Sociocultural competence in language learning and teaching. Council of Europe Publishing, 1997, p.13.

[8] M. Byram, B. Gribkova, H. Starkey, Developing the intercultura dimension in language teaching. Language Policy Division, Directorate of School, Out-of-School and Higher Education DGIV, Council of Europe, Strasbourg, 2002

[9] O.A. Dmitrieva, Linguocultural type: constitutive features. Axiologica $\begin{array}{llll}\text { Linguistics. } & \text { Volgograd, } & \text { 2009, } & \end{array}$ 